https://doi.org/10.18778/7525-969-8.07

Andrzej Krzak

\title{
Słowenia - początek końca Jugosławii. Wojna dziesięciodniowa
}

\section{Charakterystyka geograficzna}

Słowenia to w większości kraj górski i wyżynny (ok. 90\% całkowitej powierzchni leży na wysokości ponad $300 \mathrm{~m}$ n.p.m.). Najwyższym szczytem tego państwa jest położony w Alpach Julijskich Triglav (2864 m n.p.m.). Ponadto prawie połowę kraju zajmują lasy. Słowenia zwykle jest dzielona na 13 krain, lecz pod względem geograficznym wyróżniamy sześć podstawowych regionów: Alpy (w tym Alpy Julijskie, Alpy Kamnicko-Savinjskie); góry Karawanki (z masywem Pohorje) wraz z obszarem subalpejskim (wyżynny obszar w okolicach miast: Idrija, Cerkno, Škofja Loka); Słowenia Centralna, Dynarski Kras, Primorje i zachodni pas Niziny Panońskiej.

Alpy Julijskie są pasmem górskim ciąnącym się równoleżnikowo na przestrzeni 100 km od północno-wschodnich Włoch po Słowenię. Ograniczone są od północy dolina Sawy, od zachodu zaś dolinami Tagliamento i Felli po linię Jubljanicy i Idrijcy ${ }^{1}$. Na lewym brzegu Sočy w kierunku do rzeki Sawy leżą masywy Porezenu i Blegoša ${ }^{2}$. Obok najwyższego szczytu, czyli Triglava, znajdują się grzbiety: Jaloviec, Krn i inne. Na północy od Alp leżą Karawanki, które rozciagają się wzdłuż granicy austriacko-słoweńskiej, między rzekami Sawą i Drawą ${ }^{3}$. Długość pasma wynosi ponad 150 km. Na wschodzie przechodzi ono w Alpy Kamnickie ${ }^{4}$ i Pohorje ${ }^{5}$.

${ }^{1}$ I.A. Božič, M.A. Knežević, Osnovi Vojne Geografije. Federatina Narodna Republika Jugoslavija, Beograd 1954, s. 87.

2 T. Lenczowski, Z. Parucki, A. Żebrowski, Austria, Finlandia, Jugosławia, Szwajcaria. Vademecum, Warszawa 1973, s. 310.

${ }^{3}$ J. Makowski, Geografia fizyczna świata, Warszawa 2008, s. 58.

${ }^{4}$ Alpy Damnickie, zwane też Alpami Savinjskimi, są najbardziej wysuniętym pasmem górskim we wschodniej części Słowenii. Stanowią południowy występ pasma Karawanki, Wielka Geografia Powszechna, Europa IV, Hiszpania, Portugalia, Włochy, Jugosławia, Bułgaria, Grecja, Albania, Turcja Europejska, red. S. Gorzuchowski, T. Dybczyński, Warszawa 1938, s. 32.

5 T. Lenczowski, Z. Parucki, A. Żebrowski, dz. cyt., s. 309. 
Karawanki charakteryzuja się urwistymi szczytami i polodowcowymi dolinami z krasowymi płaskowyżami ${ }^{6}$. Jest tam szereg przełęczy, np.: Seeberg czy Ljubelj. Najwyższym szczytem jest Hochstuhl - 2238 m n.p.m. Na południowy zachód i południe rozciaga się obszar wyżynny, pokryty licznymi wzgórzami, ciagnący się aż do Słowenii Środkowej.

Kras, położony pomiędzy Alpami Julijskimi a Morzem Adriatyckim, stanowi rozległy, wapienny płaskowyż o średniej wysokości od 300 do 500 m n.p.m. Charakterystycznym zjawiskiem są tu zanikające rzeki, np. Pivka, oraz systemy podziemnych jaskiń. Płaskowyż jest podzielony na trzy części przez doliny rzek Kupy, Idrijcy i Reki. Z kolei południowo-wschodni odcinek, ciagnący się do granicy z Chorwacja, charakteryzuje się licznymi płaskowyżami, wzniesieniami i mniejszymi masywami górskimi.

Basen Lublański - Centralna Słowenia - obejmuje tzw. basen Lublański (Lubjlanski) i okoliczne pasma wzgórz. Od północy ograniczony jest Alpami, natomiast na południu krasem Gór Dynarskich. Powstał u zbiegu rzek alpejskich, które utworzyły doliny i kotliny prawie we wszystkich kierunkach, z wyjątkiem północy, gdzie znajdują się pasma górskie. Tutaj przecinają się główne szlaki komunikacyjne z Europy Zachodniej na Bałkany i dalej do Azji Mniejszej.

Prekomurje - zachodni pas Niziny Panońskiej, gdzie występują góry zrębowe, dochodzące do wysokości 1060 m n.p.m. Ma charakter płaskowyźów ${ }^{7}$. Na zachód od Prekomurja rozciaga się Pogórze Alp, które sięga na wschodzie po Lublańską Kotlinę. Na wschodzie Prekomurje ogranicza rzeka Mura, która między wioskami Štrigova i Domašiniec jest rzeką graniczną pomiędzy Słowenią a Chorwacją. Prekomurje ma dogodne połączenie z zachodnimi Węgrami ${ }^{8}$.

Primorje (Primorska) - południowo-zachodni obszar kraju zajmuje wąska nizina, rozciagająca się wzdłuż wybrzeża Morza Adriatyckiego, nad Zatoka Triesteńska.

Słowenię przecinają dwie rzeki Sawa i Drawa, obie płynące w kierunku południowo-zachodnim i wpadające do Dunaju. Sawa z Krką i Drawa z Mura, poprzez Dunaj, należą do zlewiska Morza Czarnego. Spośród innych większych rzek należy wymienić, wpadającą do Adriatyku, Sočę - na zachodzie, Murę - na północnym wschodzie, Krkę - na południowym wschodzie oraz Kupę, stanowiąca na odcinku południowo-wschodnim granicę z Chorwacja. Spośród jezior Słowenii do najbardziej znanych zaliczamy jeziora polodowcowe, to Cerknica, Bohinjskie, Bied i Triglavskie, jednak największym zbiornikiem wód stałych jest sztuczne Jezioro Šmartinsko, położone w pobliżu miasta Celje.

\footnotetext{
${ }^{6}$ Wielka Geografia Powszechna..., s. 32.

7 Tamíe, s. 31.

8 I.A. Božič, M.A. Knežević, dz. cyt., s. 92.

${ }^{9}$ Soča wraz ze swoimi dopływami należy do zlewiska Morza Adriatyckiego.
} 
W zachodniej części Słowenii występuje klimat śródziemnomorski, a pozostały obszar kraju jest pod wpływem klimatu kontynentalnego ciepłego. $\mathrm{Na}$ północnym zachodzie dominuje klimat alpejski w związku z oddziaływaniem silnych wpływów znad Atlantyku i obfitymi opadami. Wybrzeże, aż do doliny Sočy, charakteryzuje się natomiast klimatem śródziemnomorskim, z ciepła, słoneczną pogodą i łagodnymi zimami. W części wschodniej kraju występuje klimat kontynentalny, z gorącymi latami i mroźnymi zimami. Średnie temperatury stycznia kształtują się w granicach od $3{ }^{\circ} \mathrm{C}$ na wybrzeżu do $-2^{\circ} \mathrm{C}$ na wschodzie kraju i $-8^{\circ} \mathrm{C}$ w Alpach. W lipcu wynoszą odpowiednio: 24,20 i $10^{\circ} \mathrm{C}$. Opady są zróżnicowane pod względem ilości i rozkładu w ciagu roku ${ }^{10}$.

Republikę Słowenii według danych szacunkowych zamieszkiwało ok. $2 \mathrm{mln}$ mieszkańców, spośród których Słoweńcy stanowią $83,1 \%{ }^{11}$. Mniejszości narodowe tworzą Serbowie, Chorwaci, Bośniacy, Węgrzy, Macedończycy, Czarnogórcy, Albańczycy i Włosi. Ludność jest nierównomiernie rozmieszczona, największe jej skupisko występuje w stolicy (wraz z okolica) oraz w pasie wybrzeża. Stolica Słowenii jest Lublana (Ljubljana).

\section{Jugosłowiańska Armia Narodowa i jej plany}

Jugosłowiańska Armia Ludowa (JNA) składała się z trzech zasadniczych rodzajów wojsk: Wojsk Lądowych, Sił Powietrznych i Obrony Przeciwlotniczej oraz Marynarki Wojennej. W latach 1945-1968 co najmniej kilka razy dokonywano w niej zmian organizacyjnych i strukturalnych ${ }^{12}$, by ostatecznie w $1968 \mathrm{r}$. wprowadzić sześć armii w miejsce okręgów armijnych oraz jeden Obszar Wojskowy, później przemianowany na Titogradzki Korpus. Ten system organizacji sił zbrojnych Jugosławii, składający się z dwóch komponentów, czyli JNA (armii) oraz Obrony Terytorialnej (TO) ${ }^{13}$, przetrwał ponad 20 lat i w literaturze przedmiotu jest określany jako republikański system wojskowy. Siły Powietrzne i Obrony Przeciwlotniczej (RV i PVO) do 1959 r. były odrębnym rodzajem wojsk.

${ }^{10}$ Najmniejsza ilość opadów występuje na wybrzeżu (ok. 800 mm rocznie), na wschodzie do $1000 \mathrm{~mm}$, a w górach opady wynoszą ponad $3000 \mathrm{~mm}$.

11 J.J. Wiatr, Stowenia - przykład udanej transformacji, „Zeszyty Naukowe” Instytutu Badań Społecznych i Międzynarodowych Fundacji im. Kazimierza KellesKrauza 1998, z. 2, s. 13.

12 Novi pocetak, stari saveznik (1961-1980), http://www.oklop.net23.net/jna/19611987.htm; Sa osloncem na zapadnu vojnu pomoc (1951-1957), http://www.oklop.net23.net/ jna/1950-1957.htm (dostęp 16 XI 2011).

${ }^{13}$ D. Marijan, Jugoslavenska Narodna Armija - važnija obilježja, „Polemos” 2006, vol. 17 , br. 9 , s. 25 . 
Marynarka Wojenna (Ratna Mornarica) została utworzona na bazie powstałej w 1942 r. Marynarki Narodowowyzwoleńczych Wojsk Jugosławii ${ }^{14}$. W 1962 r. $\mathrm{w}$ trakcie reorganizacji została przemianowana $\mathrm{w} 4 \mathrm{~A}$ i pod taką nazwa przetrwała do 1969 r., kiedy w wyniku kolejnych zmian strukturalnych weszła w skład powstałego Morskiego Okręgu Wojskowego (VPO), który dzielił się na marynarkę wojenną i jednostki stacjonujące na lądzie (wybrzeżu).

W latach 1986-1987 rozpoczęto prace koncepcyjne nad przebudowa sił zbrojnych Jugosławii, co doprowadziło m.in. do wydania Decyzji o przebudowie organizacji sit zbrojnych oraz systemu dowodzenia $i$ kierowania sitami zbrojnymi SFRJ, która wprowadziła rewolucyjne zmiany w organizacji wojsk Jugosławii. 1 listopada 1987 r. zmieniono nazwę Sztabu Generalnego JNA na Sztab Generalny Sił Zbrojnych SFRJ ${ }^{15}$. Szczególnie ostro przeciwko tym modyfikacjom protestowali Słoweńcy, którzy uważali, że należy zrewidować decyzję Prezydium SFRJ ${ }^{16}$. Ich opinie nie zostały jednak wzięte pod uwagę, „Jedinstvo” wprowadzono. 25 grudnia jednostki i administracja sił zbrojnych Jugosławii rozpoczęły wdrażanie zmian $\mathrm{w}$ organizacji armii ${ }^{17}$. Likwidacji uległy wszystkie armie, w miejsce których wprowadzono okręgi wojskowe. Dowódcom VO podporzą dkowano także republikańskie jednostki i sztaby $\mathrm{TO}^{18}$. Reorganizacji uległy również Siły Powietrzne i Obrony Przeciwlotniczej. Ostatecznie utworzono trzy korpusy: 5., 1., 3. KRV i PVO, przyporządkowując je do nowo powstałych okręgów. Wojskowomorski Okręg pozostawiono bez zmian, rozszerzając jednak jego odpowiedzialność operacyjną o półwysep Istria. Ponadto podporządkowano dowództwu VPO - 9. Kninski Korpus.

$\mathrm{Na}$ terytorium Słowenii stacjonowały jednostki 14. i 31. korpusów, wchodzące w skład 5. Okręgu Wojskowego (OW). Okręg ten w czasie pokoju liczył ok. 35 tys. żołnierzy oraz pracowników cywilnych ${ }^{19}$. Obok dwóch korpusów,

${ }^{14}$ Właściwie Jugoslavenska ratna mornarica (JRM), zob. Ratna mornarica, pomorstvo i riječno brodarstvo Jugoslavije, Split [b.r.w.], s. 24-26.

${ }^{15}$ Služebni vojni list, Beograd, 13.10.1987, s. 853.

${ }^{16}$ D. Marijan, Slom Titove Armije. JNA i raspad Jugoslavije 1987.-1992., Zagreb 2008, s. 109.

${ }_{17}$ Plan „Jedinstvo” miał być wdrażany w kilku (dokładnie trzech) fazach do końca 1990 r., tak aby w strukturze „P” (organizacja wojsk czasu pokoju) siły zbrojne osiagnęły liczebność ok. 300 tys. ludzi, w tym 186 tys. żołnierzy w jednostkach bojowych. D. Marijan, "Jedinstvo" - posljednji ustroj JNA, „Polemos” 2003, vol. 6, br. 1-2, s. 17.

${ }^{18}$ D. Marijan, Slom Titove..., s. 113-114.

${ }_{19}$ N. Thomas, K. Mikulan, The Yugoslav Wars (1). Slovenia and Croatia 1991-95, Oxford 2006, s. 8; A. Bebler, Yugoslavia's Agony Civil War Becomes Savage Chaos, „International Defense Review” 1992, no. 9, s. 815; Osamosvojitev Slovenije, Raziskovalni projekt, http://www.zrss.si/gradivozauciteljezgodovine/ Raziskovalni_projekt_Osamosvojitev_SLO.pdf (dostęp 21 XI 2011); Jugoslavenska Narodna Armija (JNA) - Yugoslav People's Army OOB 1990, http://www.scribd.com/doc/51606312/JNAJugoslovenska-Narodna-Armija (dostęp 21 XI 2011). 
które dyslokowane były na obszarze Słowenii, w skład 5. OW wchodziły także korpusy: 13. (Rijeka), 32. (Varaždin) i 10. (Zagrzeb). Dowódca okręgu dysponował więc w Republice Słowenii znacznymi siłami, w skład których wchodziło 115 czołgów, 82 bojowe wozy piechoty i transportery opancerzone, 32 działa samobieżne, kilkanaście zestawów artylerii przeciwpancernej i przeciwlotniczej (samobieżnych i holowanych), ok. 20 samolotów myśliwsko-bombowych i 24 śmigłowce ${ }^{20}$. Nie wszystkie jednostki korpuśne miały pełne stany etatowe, dlatego też gotowych „do użycia” było ok. 3 tys. żołnierzy ${ }^{21}$. 14. Korpus (Lubljanski) miał liczyć ok. 14 tys. ludzi, natomiast 31. Korpus (Mariborski) - ok. 6,3 tys. ${ }^{22}$ Dowództwo OW mogło także użyć pozostałych sił okręgu oraz uzyskać wsparcie sił federalnych.

Przed rozpoczęciem działań wojennych JNA liczyła ok. 180 tys. żołnierzy w służbie czynnej ${ }^{23}$ oraz ok. 510 tys. w rezerwie (według innych źródeł było ich ok. 1,2 mln), w tym w siłach lądowych ok. 140 tys. oficerów, podoficerów, żołnierzy zasadniczej służby i pracowników cywilnych. Na uzbrojeniu miała prawie 4,1 tys. czołgów, bojowych wozów piechoty i transporterów opancerzonych różnych typów, ok. 19,9 tys. dział i moździerzy (w tym przeciwpancernych i przeciwlotniczych), 1 tys. wyrzutni artylerii rakietowej, 300 samobieżnych wyrzutni $\mathrm{PPK}^{24}$, ponad 2,3 tys. wyrzutni i zestawów rakiet przeciwlotniczych ${ }^{25}$. Marynarka wojenna liczyła ok. 10 tys. żołnierzy i dysponowała 11 okrętami podwodnymi, 4 fregatami, 15 kutrami i okrętami rakietowymi oraz innymi jednostkami bojowymi i pomocniczymi. Ponadto siły morskie dysponowały brzegową artylerią lufową i rakietową ${ }^{26}$. Siły powietrzne liczyły ok. 32 tys. osób, a na ich wyposażeniu znajdowało się ok. 455 maszyn bojowych i 198 helikopterów. Obronę przestrzeni powietrznej zapewniało 14 dywizjonów rakiet przeciwlotniczych i 15 pułków artylerii przeciwlotniczej ${ }^{27}$.

Dowództwo sił federalnych i kierownictwo jugosłowiańskie nie spodziewały się, że Słowenia jest w stanie przeciwstawić się JNA. Błędnie założono, że Słoweńcy, nie posiadając zorganizowanych sił, nie będą walczyć z jednostkami pancernymi i zmechanizowanymi armii federalnej. Miały to potwierdzać dane otrzymane od wywiadu i kontrwywiadu wojskowego. Dlatego też Sztab Generalny, na czele z gen. Veljko Kadijeviciem, postanowił przeprowadzić

${ }^{20}$ A. Bebler, dz. cyt., s. 815 .

${ }_{21}$ Tamize.

22 Jugoslavenska Narodna..., s. 14-15.

${ }_{23}$ Tami்e, s. 8.

${ }^{24} \mathrm{PPK}$ - przeciwpancerny pocisk kierowany.

25 The Military Balance 1990-1991, London 1990, s. 95; The Yugoslav People's ArmyJNA (History/Stat), http://illyria.proboards.com/index.cgi?board=balkanmilitarywars \&action=display\&thread=23529 (dostęp 1 XI 2011).

${ }_{26}$ The Military Balance..., s. 95-96.

${ }_{27}$ Tamże, s. 96. 
działania demonstracyjne, wysyłając kolumny zmechanizowano-pancerne, które miały zajać w pierwszej fazie przejścia graniczne, a następnie przekazać je funkcjonariuszom federalnym. Ponadto jednostki federalne miały opanować oba lotniska (Brnik i Maribor), całkowicie izolując zbuntowaną republikę. Aby opanować część przejść granicznych Sztab Generalny Federacji postanowił użyć spadochroniarzy z elitarnej 63. Brygady Powietrzno-Desantowej. Należy podkreślić, że armia federalna nie przygotowała odrębnego planu działania na wypadek secesji jednej z republik związkowych, a działania, jakie przedsięwzięto po ogłoszeniu niepodległości Słowenii miały charakter prowizoryczny i doraźny. Jugosłowiańskie dowództwo dość naiwnie sądziło, że sam potencjał zdoła złamać wolę walki Słoweńców. Nie przewidziano, że zarówno władze, jak i społeczeństwo Słowenii będą na tyle zdeterminowane, by jednak podjąć działania przeciwko regularnej armii.

\section{Powstanie słoweńskiej Obrony Terytorialnej}

W tym samym czasie, gdy rząd republikański toczył polityczną batalię o poborowych, od połowy 1990 r. minister obrony Słowenii, Janez Janša, pracował nad tym, by z TO Słowenii uczynić autonomiczną siłę militarna, która byłaby w stanie sprostać JNA. Należy podkreślić, że J. Janša był zagorzałym przeciwnikiem federacji i jugosłowiańskich sił zbrojnych.

Wiosną $1990 \mathrm{r}$. w ramach republikańskiego ministerstwa obrony powstała odrębna struktura dowodzenia, ukryta i dublująca tę, którą kierowali oficerowie wierni federacji. W stosunkowo krótkim czasie udało się zorganizować zalażek przyszłego korpusu dowódczego spośród Słoweńców służących w jednostkach TO i JNA oraz licznego grona emerytowanych oficerów ${ }^{28}$. Struktura, która w ten sposób powstała, nosiła nazwę: Manewrowe Siły Obrony Narodowej (Maneurska Struktura Narodne Zaščite, MSNZ) ${ }^{29}$. Na jej czele stanał Tonet Krkovič. W skład MSNZ mogli wejść członkowie (żołnierze i oficerowie) Obrony Terytorialnej, Obrony Cywilnej, policji, a nawet zwykli obywatele słoweńscy niezwiązani z resortami siłowymi ${ }^{30}$. Szczególną zaletą Obrony Terytorialnej Słowenii była jej homogeniczność etniczna.

28 Balkan Battlegrounds: A Military History of the Yugoslav Conflict, 1990-1995, vol. 1, Washington 2003, s. 51.

${ }^{29}$ N. Thomas, K. Mikulan, dz. cyt., s. 13; N. Baumkirher, Posavje v vojni za obrambo neodvisnosti Slovenije leto 1991, Ljubljana 2009, s. 36; K. Nanut, Teritorialna obramba na Slovenskem 1968-1990, „Revija Veteran” 2008, št. 37, s. 10.

${ }^{30} \mathrm{~V}$. Krajnc, Organizacija in značilnosti vodenja in poveljevanja v osamosvajanju Slovenije 1990/91, „Vojaška Zgodovina” 2005, št. 1/05 (9); Vojna za Slovenijo 1991 (simpozij, 26. in 27. november 2002, 3. del), ur. K. Nanut, s. 5. 
W połowie maja $1990 \mathrm{r}$. minister obrony J. Janša oraz minister spraw wewnętrznych Igor Bavčar, opierając się na MSNZ jako legalnym mechanizmie władz republikańskich, rozpoczęli proces tajnego przekształcania w konspiracyjna armię TO Słowenii oraz wybranych jednostek policji specjalnej Ministerstwa Spraw Wewnętrznych. Na czele tej „pierwszej podziemnej armii” stał sztab główny, któremu początkowo podlegało 13 regionalnych poddowództw. Ich dowódcy zostali starannie wyselekcjonowani przez przywódców Słowenii ${ }^{31}$. W ciagu niespełna trzech miesięcy Słoweńcom udało się stworzyć ponad dwudziestotysięczną tajną armię ${ }^{32}$, o której istnieniu nie wiedział ani rząd federalny, ani kontrwywiad wojskowy JNA ${ }^{33}$. 28 września 1990 r. słoweńska Skupsztina przegłosowała poprawkę do ustawy konstytucyjnej Republiki Słowenii dotyczącą organizacji systemu obrony republiki. Na jej mocy rząd republiki miał powoływać, podległego jej władzom, dowódcę Obrony Terytorialnej. Zmiana zapowiadała także zawieszenie finansowania federalnych sił zbrojnych z budżetu republikańskiego ${ }^{34}$.

W kwietniu i maju 1991 r., na mocy ustawy z 29 marca 1991 r. o obronie i ochronie ${ }^{35}$, dokonano pierwszej modyfikacji struktur TO, tworząc siedem okręgów wojskowych i Sztab Główny (Dowództwo Główne lub TO). Każdy z okręgów dzielił się na podokręgi w liczbie od dwóch do pięciu. W kwietniu 1991 r. Słoweńcy posiadali łącznie 12 brygad i 10 samodzielnych oddziałów oraz kilkanaście jednostek specjalnych ${ }^{36}$. Po mobilizacji ogłoszonej w czerwcu $1991 \mathrm{r}$. siły słoweńskie miały pod bronią, według różnych szacunków, od 20 do 23 tys. żołnierzy, a Ordre de Bataille TO Słowenii przedstawiał się następująco:

Główne Dowództwo (Ljubljana): 30. Grupa Szybkiego Reagowania/Specjalna Brygada Ministra Obrony; 9. Brygada Przeciwlotnicza; jednostka helikopterów; 510. i 710. centra szkoleniowe; 130. Instytut Techniczny; Kompania „Gwardia i Honor"; Dolenjski Okręg Wojskowy (Dowództwo Novo Mesto): 21., 23., 25., 27. podokręgi wojskowe; 25. Brygada; Gorenjski Okręg Wojskowy (Kranj): 31., 33., 35. podokręgi wojskowe; 21., 22., 31., 32. i 34. brygady; Juznoprimorski (Południowe Wybrzeże) Okręg Wojskowy (Postolnja): 41., 43., 45., 47. podokręgi wojskowe; Ljubljanski Okręg Wojskowy (Ljubljana): 51., 53., 55., 57. podokręgi wojskowe; Severnoprimorski (Północne Wybrzeże) Okręg Wojskowy (Nova Gorica): 61., 63. podokręgi wojskowe; Vzhodnostajerski (Wschodnia Styria) Okręg Wojskowy (Maribor): 71., 73., 75., 77., podokręgi wojskowe;

${ }^{31}$ Balkan Battlegrounds..., s. 52.

${ }^{32}$ Niki Baumkirher w swojej pracy podaje, że przeszkolono i uzbrojono ponad 21 tys. członków MSND. N. Baumkirher, dz. cyt., s. 37.

${ }^{33}$ L. Silber, A. Little, Yugoslavia. Death of a Nation, New York 1996, s. 106.

${ }_{34}$ V. Krajnc, dz. cyt., s. 55-56.

${ }_{35}$ Tamże, s. $57-58$.

${ }^{36}$ О. Валецкий, Юугославская Война 1991-1995 годьь, Москва 2008, s. 11-12. 
72. Brygada, trzy wzmocnione grupy batalionowe; Zahodnostajerski (Zachodnia Styria) Okręg Wojskowy MD (Celje): 81., 83., 85., 87., 89. podokręgi wojskowe ${ }^{37}$. Zasadniczym mankamentem nowo utworzonych sił był brak środków walki, zwłaszcza broni i systemów przeciwpancernych oraz przeciwlotniczych. W tej sytuacji J. Janša i jego współpracownicy (zwłaszcza Janez Šlapar), obawiali się, że w konfrontacji z nowoczesną techniką słoweńscy żołnierze poniosą duże straty i nie zdołaja przejąc inicjatywy. Uważano, że jedynym sposobem, aby zmienić tę niekorzystną sytuację jest dozbrojenie oddziałów TO, dlatego też niezbędne okazało się dokonanie zakupu środków walki oraz amunicji. Znaczną ilość uzbrojenia i amunicji Słowenia nabyła poza granicami kraju. Według ocen analityków CIA, Słoweńcom prawdopodobnie udało się zakupić co najmniej kilka tysięcy sztuk broni piechoty ${ }^{38}$. W grudniu $1990 \mathrm{r}$. nabyli nieznaną ilość wyprodukowanych w Singapurze ręcznych przeciwpancernych granatników typu Armbrust ${ }^{39}$. Oprócz broni, w ramach przeprowadzonej 17 czerwca 1991 r. operacji, Słoweńcy pozyskali od jednego z państw zachodnich sprzęt łączności, który zapewniał im bezpieczną komunikację ${ }^{40} .21$ czerwca dotarł do Słowenii ostatni, tajny transport broni. Zawierał on 5 tys. karabinów automatycznych oraz 5 mln pocisków amunicji, jak również wyrzutnie przeciwpancernych pocisków kierowanych wraz z rakietami typu AT-4 oraz kilka tuzinów pocisków przeciwlotniczych SA-7 ${ }^{41}$. Według J. Janšy, do czerwca 1991 r. TO Słowenii posiadały na swoim wyposażeniu 23 tys. sztuk broni piechoty (z ograniczonym zasobem amunicji) i ok. 1 tys. sztuk środków zwalczania czołgów i wozów bojowych ${ }^{42}$.

\section{Jednostki Ministerstwa Spraw Wewnętrznych i inne siły Słowenii}

Obok jednostek TO, w walkach z JNA aktywny udział wzięły jednostki policji podległe republikańskiemu Ministerstwu Spraw Wewnętrznych (Mini-

${ }^{37}$ N. Thomas, K. Mikulan, $d z$. cyt., s. 14.

${ }^{38}$ Balkan Battlegrounds..., s. 54; L. Silber, A. Little, dz. cyt., s. 106-107.

${ }^{39}$ Armbrust (z jęz. niem. - kusza) - niemiecki ręczny granatnik przeciwpancerny. Kaliber: $67 \mathrm{~mm}$; waga wyrzutni 6,3 kg, donośność do $300 \mathrm{~m}$, przebijalność do $400 \mathrm{~mm}$, J. Szymański, R. Woźniak, Granatniki przeciwpancerne (II), „Nowa Technika Wojskowa” 1995 , nr 12, s. $14-16$.

${ }^{40}$ J. Jansa, The Making of the Slovenian State, 1988-1992: The Collapse of Yugoslavia, Ljubljana 1994, s. 140-141.

${ }^{41}$ Balkan Battlegrounds..., s. 54.

${ }^{2} 90 \mathrm{~mm}$ ręczna wyrzutnia ppanc. typu „OSA”. Maksymalna donośność do $1900 \mathrm{~m}$, minimalna $360 \mathrm{~m}$ (według innych źródeł do $500 \mathrm{~m}$ ). Przebijalność pancerza do $350 \mathrm{~mm}$, Hand-Held rocket launcher RBR-90 mm M79 „OSA”, http://eurokompozit.com.mk/ LAUNCHER/osa/OSA\%20800X600.htm (dostęp 21 XI 2011). 
starstvo Unutarnjih Poslova, MUP), kierowanemu przez I. Bavčara. Przed rozpoczęciem walk na słoweńskiej policji spoczywał obowiązek prowadzenia wywiadu i rozpoznania. W trakcie działań wojennych jednostki specjalne policji wraz z oddziałami TO uczestniczyły w bezpośrednich starciach z JNA. Policja porządkowa i drogowa z kolei zajmowała się zakładaniem blokad i utrzymaniem porządku publicznego ${ }^{43}$.

Do jednostek słoweńskiego systemu obrony należy zaliczyć kilkunastotysięczne oddziały obrony narodowej (Narodna Zascita, NZ) oraz jednostki obrony cywilnej (Civilna Zascita, CZ) ${ }^{44}$. Zadaniem NZ była ochrona i obrona zakładów przemysłowych, budynków i dróg. Ponadto w marcu $1991 \mathrm{r}$. skrajnie prawicowe ugrupowania rozpoczęły formowanie paramilitarnych grup pod nazwą Słoweńska Gwardia (Slovenska Garda, GS) oraz Gwardziści (Gardisti lub Slovenske Gardi$s t i)^{45}$. Obie organizacje zostały jednak rozwiązane, a ich przywódcy aresztowani ${ }^{46}$.

\section{Plany strony słoweńskiej}

Ministerstwo Spraw Wewnętrznych prawie na rok przed kryzysem rozpoczęło planowanie działań na wypadek wystapienia sytuacji kryzysowej. W lipcu 1990 r., po objęciu rządów przez polityków koalicji DEMOS, nakazano opracowanie wytycznych na wypadek próby obalenia legalnych władz republiki. Były one tworzone w celu przygotowania jednego z resortów siłowych do konfrontacji z siłami federalnymi. W ten sposób powstał tajny dokument, zatytułowany Plan „25 lipca”, który zawierał kilka wariantów działań na wypadek, gdyby jednostki sił federalnych przeprowadziły interwencję na terytorium Słowenii. Do końca listopada $1990 \mathrm{r}$. władze republiki potajemnie opracowywały również plan zabezpieczenia międzynarodowych granic Słowenii oddziałami policji. Plany słoweńskie opierały się na założeniu, że siły federalne w pierwszym etapie działań będą dysponowały oddziałami i związkami taktycznymi co najmniej dwóch korpusów. Spodziewano się, że będą one dążyć do opanowania newralgicznych punktów w państwie i zastraszenia władz republikańskich, aby te podjęły rozmowy z Belgradem. W kolejnej fazie wojny armia federalna, dysponująca siłami całego 5. OW oraz prawdopodobnie jednostkami 1. i 3. OW, uzupełnionymi po mobilizacji, miała opanować republikę i przywrócić kontrolę władz federalnych

${ }^{43}$ Balkan Battlegrounds..., s. 53.

${ }^{44}$ Tamize.

${ }_{45}$ Bojówki te były formowane przez przywódcę Słoweńskiej Partii Narodowej, Zmago Jelinčiča, który po ich rozwiązaniu został aresztowany w czerwcu $1991 \mathrm{r}$.

${ }^{46}$ N. Thomas, K. Mikulan, dz. cyt., s. 15. 
nad nia. Dlatego też siły TO, wsparte przez jednostki specjalne policji, planowały podjęcie działań zmierzajacych do odizolowania garnizonów JNA w Słowenii poprzez ich zablokowanie. Kolejnym krokiem było przejęcie magazynów amunicji i uzbrojenia wojsk federalnych oraz pozwolenie interweniującym wojskom na wejście w głąb terytoriom Słowenii. Następnie miano je zablokować i odizolować. Celem było niedopuszczenie do nich kolejnych posiłków, a potem zniszczenie lub zmuszenie do poddania się $\operatorname{si}^{47}$.

\section{Droga do konfliktu - przyczyny wybuchu wojny dziesięciodniowej}

Jak słusznie zauważył Adam Koseski ${ }^{48}$, Słowenia nie miała żadnych tradycji państwotwórczych, gdy 25 czerwca 1991 r. Ljubljana ogłosiła niepodległośćs ${ }^{49}$. Zdawać by się więc mogło, że opuszczenie federacji było wynikiem impulsywnej decyzji polityków i społeczności słoweńskiej. Taka konstatacja byłaby jednak daleko posuniętym uproszczeniem, podwaliny do uzyskania przez Słowenię niepodległości kształtowały się bowiem na długo przed secesją z SFRJ. Były one poprzedzone szeregiem politycznych, ekonomicznych oraz militarnych wydarzeń $^{50}$, a ich punktem kulminacyjnym stała się wojna dziesięciodniowa, która przyniosła Słoweńcom niepodległość.

Centroprawicowa koalicja DEMOS przyjęła w lipcu 1990 r. deklarację parlamentarna, zgodnie z którą prawa republiki zyskały pierwszeństwo przed konstytucją federalna, a Ljubljana miała prowadzić własną politykę zagraniczna i obronna. Od tego momentu dążenia Słowenii do uzyskania niepodległości coraz bardziej przybierały na sile. We wrześniu 1990 r. Ljubljana przejęła kontrolę nad TO, w grudniu 1990 r. przeprowadzono referendum dotyczące pełnej niepodległości, w którym większość mieszkańców głosowała za „niepodległym i suwerennym państwem", natomiast w marcu 1991 r. republika odmówiła

${ }^{47}$ D. Guštin, Slovenija saveznica Hrvatske tijekom razlaza s jugoslavenskom državom (od „nenačelne koalicje” do rospada vojnog saveza 1989-1991), „Časopis za suvremenu povijest" 2008 , br. 1, s. 93-98.

${ }^{48}$ A. Koseski, Bałkańskie konflikty etniczne na przełomie XX $i$ XXI stulecia, [w:] Bałkany. Etnokulturowe podtoże konfliktów, red. W. Konarski, A. Koseski, Pułtusk 2006, s. 104.

${ }^{49}$ D. Gibas-Krzak, A. Krzak, Południowosłowiańska mozaika. Charakterystyka geograficzno-polityczna państw postjugosłowiańskich, Szczecin 2010, s. 116.

${ }_{50}$ M. Waldenberg, Rozbicie Jugostawii. Od separacji Stowenii do wojny kosowskiej, Warszawa 2003, s. 65; J. Krulic, Storia della Yugoslavia dal 1945 ai nostri giorni, Milano 1997, s. 90-92; M.J. Zacharias, „Chorwacka wiosna” i serbski „liberalizm”. Konflikty polityczne w Jugosławii na poczatku lat siedemdziesiatych, „Dzieje Najnowsze” 2000, nr 2, s. 99-106, 110-116 i n. 
wysłania swojego dorocznego kontyngentu poborowych do odbycia rocznej służby wojskowej w armii federalnej ${ }^{51}$. Doprowadziło to do kilkunastomiesięcznego konfliktu z władzami federalnymi, stanowiąc ciagły powód starć między Belgradem a Ljubljana. Przywódcy Słowenii mieli nadzieję na stopniowe zwiększenie odsetka poborowych służących w kraju, aż do chwili, gdy wszyscy słoweńscy rekruci służyliby w granicach republiki, co było jednak niezgodne z obowiąujacym prawem.

Należy podkreślić, że strona słoweńska nie dążyła do osiągnięcia porozumienia z władzami federacji. Świadczą o tym rozmowy, jakie zainicjowali politycy koalicji DEMOS z przywódcami Chorwackiej Wspólnoty Demokratycznej $(\mathrm{HDZ})^{52}$, których wynikiem było zacieśnienie więzów i opracowanie wspólnego planu działania na wypadek konfliktu z władzami federalnymi.

W połowie maja $1991 \mathrm{r}$. doszło do dalszego zaostrzenia sytuacji w związku z żądaniem dowódcy 5. OW, gen. płk. Konrada Kolšeka, skierowanym do władz republikańskich, aby wstrzymały szkolenie słoweńskich TO w ośrodkach w Pekre oraz $\operatorname{Ig}^{53}$. W odpowiedzi Słoweńcy rozmieścili w rejonie ośrodków dwie kompanie „antykomandosów”. Jednocześnie dowództwo federalne próbowało podjać rozmowy z władzami Słowenii, jednak propozycja JNA pozostała bez odpowiedzi. W tym samym czasie Szef Sztabu Generalnego JNA, gen. płk Blagoje Adžić osobiście wydał instrukcje gen. K. Kolšekowi oraz dowódcom obu korpusów JNA (14. Ljubljanskiego i 31. Mariborskiego) ${ }^{54}$ dotyczące zamknięcia obydwóch ośrodków szkoleniowych. Według planów armii federalnej, najpierw miał zostać opanowany ośrodek w Pekre w pobliżu Mariboru (710. Centrum Szkoleniowe). Jego zajęcie powierzono jednostkom specjalnym z Zagrzebia (z 31. bVP), które miały być wsparte czołgami ze 195. Brygady Zmotoryzowanej (BZmot.) ${ }^{55}$.

21 maja 1991 r. K. Kolšek spotkał się z premierem Słowenii, Lojze Peterle, by domagać się sprawozdań z poboru żołnierzy w republice oraz zamknięcia obu ośrodków szkoleniowych. Słoweńcy próbowali opóźnić konfrontację i zaproponowali dalsze rozmowy. JNA nie mogła jednak przyjać tej propozycji i dwa

${ }^{51}$ Tamíe, s. 50.

52 Już po zakończeniu konfliktu, w trakcie jednej z debat, do jakiej doszło w telewizji słoweńskiej, Franjo Tuđman i Milan Kučan przyznali, iż w połowie 1990 r. ich celem było prowadzenie wspólnej akcji politycznej i wojskowej, która miała doprowadzić do unicestwienia Jugosławii. W debacie tej uczestniczył także gen. Martin Špegelj oraz były przywódca komunistów słoweńskich Ciril Ribičič (przewodniczący SDP, powstałej po rozformowaniu Związku Komunistów Słowenii). Propozycja utworzenia konfederacji była zasłoną dla prawdziwego celu, czyli likwidacji federacji i utworzenia niezawisłych republik, Chorwacji i Słowenii. Н. Василева, В. Гаврилов, Балканский тупик? Историческая судьба Югославии в ХХ веке, Москва 2000, s. 328.

${ }^{53}$ V. Krajnc, dz. cyt., s. 60.

54 Jednostki tych korpusów stacjonowały na terytorium Słowenii.

55 Balkan Battlegrounds..., s. 57. 
dni później wysłała grupę bojowa do 710. Ośrodka Szkoleniowego z żądaniem odesłania słoweńskich poborowych do armii federalnej ${ }^{56} .24$ maja bliską wybuchu otwartego konfliktu zbrojnego sytuację dodatkowo zaogniło zatrzymanie okręgowego dowódcy TO Słowenii, Vladimirja Miloševiča, Milka Ozmeca oraz kilku innych osób ${ }^{57}$. Generał B. Adžić miał nadzieję, że w ten sposób wymusi na władzach zamknięcie ośrodków oraz odesłanie poborowych do jednostek federalnych. W odpowiedzi Słoweńcy odcięli prąd i sieć telefoniczną garnizonom JNA w całej republice. Posunięcie okazało się skuteczne. Dowództwo JNA ugięło się i wypuściło zatrzymanych ${ }^{58}$. Słoweńcy wygrali następna „małą potyczkę”, po raz kolejny zmuszając wyższych dowódców armii federalnej do wycofania się z wcześniej podjętego zamiaru.

\section{Wojna dziesięciodniowa}

\section{PIERWSZE STRZAŁY: WALKA O POSTERUNKI GRANICZNE (25-28 CZERWCA)}

Ostatecznym powodem rozpoczęcia działań militarnych przez armię federalną było jednak ogłoszenie niepodległości przez Słowenię, do czego doszło 25 czerwca 1991 r. $^{59}$, a co było równoznaczne z secesja. Należy podkreślić, że oficjalnie uważa się, iż niepodległość tego kraju została ogłoszona 26 czerwca $^{60}$, jednak sam akt i rozpoczęcie jego wykonania nastapiło już 25 czerwca. Było to zamierzone działanie władz słoweńskich, którym udało się zaskoczyć władze federalne i dowództwo JNA. Słoweńcy liczyli, że zdołają szybko zająć posterunki graniczne i newralgiczne punkty w kraju (m.in. lotniska międzynarodowe) ${ }^{61}$.

56 J. Jansa, dz. cyt., s. 116-124.

${ }^{57}$ V. Krajnc, dz. cyt., s. 60.

${ }^{58}$ Po 14 godzinach negocjacji Słoweńcy zostali wypuszczeni, jednak nie podjęto żadnych innych uzgodnień, które pozwoliłyby na rozwiązanie kryzysu.

${ }^{59}$ D. Gibas-Krzak, A. Krzak, dz. cyt., s. 116.

${ }^{60}$ Leszek Podhorodecki podał, iż Chorwacja i Słowenia ogłosiły niepodległość 25 czerwca. Podobną datę, lecz w odniesieniu tylko do Słowenii, zaprezentowali amerykańscy analitycy CIA. Stwierdzili oni jednak, że oficjalnie stało się to 26 czerwca, natomiast J. Janša w swoich wspomnieniach poinformował, iż odbyło się to na sesji zamkniętej parlamentu. Z kolei Michał Jerzy Zacharias podał, że F. Tuđman i M. Kučan podczas spotkania 15 czerwca 1991 r. w Ljubljanie uzgodnili, iż niepodległość Słowenii i Chorwacji zostanie ogłoszona najpóźniej 26 czerwca. L. Podhorodecki, Jugosławia. Dzieje narodów, państw i rozpad federacji, Warszawa 2000, s. 199; Balkan Battlegrounds..., s. 58; M.J. Zacharias, Komunizm, federacja, nacjonalizm. System władzy w Jugosławii 1943-1991. Powstanie, przekształcenia, rozkład, Warszawa 2004, s. 534.

${ }^{61}$ W. Szulik, Konflikt w byłej Jugosławii, „Sprawy Międzynarodowe” 1997, nr 1, s. 96. 
Tak o tym fakcie napisał we swoich wspomnieniach J. Janša: „Cały czas ostrzegałem, że formalne uchwały o deklaracji niepodległości muszą zostać podjęte przed 26 czerwca podczas zamkniętej sesji, co umożliwiłoby nam [...] zyskanie przewagi nad potencjalnymi reakcjami federacji, zwłaszcza militarnymi, oraz że powinniśmy zyskać suwerenność w trzech kluczowych aspektach: kontroli granicznej, kontroli celnej oraz kontroli powietrznej [...] to właśnie ten jeden dzień miał kluczowe znaczenie, ponieważ 25 czerwca, natychmiast po deklaracji praw, przejęliśmy punkty odprawy celnej, przejścia graniczne oraz kontrolę ruchu lotniczego, nie oddawszy nawet jednego strzału. W Belgradzie przekonani byli praktycznie do ostatniej sekundy, że deklaracja niepodległości będzie miała miejsce 26 czerwca [...]. Z tego powodu planowali swoją interwencję z rana 27 czerwca, na moment, w którym, jak sądzili, decyzja Słowenii nadal będzie na papierze" ${ }^{\prime 2}$.

Władze republikańskie od dłuższego czasu były bowiem zdecydowane na secesję. Należałoby ostatecznie obalić niektóre ciagle pokutujace twierdzenia, jakoby to Serbowie ze Slobodanem Miloševiciem byli odpowiedzialni za rozpoczęcie tragicznego w skutkach konfliktu jugosłowiańskiego. Niewątpliwie sam przywódca serbski miał niemały wpływ na wybuch wojny domowej w byłej Jugosławii, lecz niewiele mniejsze „zasługi” w tym dziele przypadają Milanowi Kučanowi i jego współpracownikom. Strona słoweńska konsekwentnie „torpedowała" wszelkie inicjatywy serbskiego prezydenta oraz Aliji Izetbegovicia i Kiro Gligorova, gdyż nie zaspokajały one prywatnych ambicji M. Kučana i innych przywódców republik federalnych. Słusznie zresztą zauważył znakomity znawca problematyki jugosłowiańskiej Michał Jerzy Zacharias, że Słoweńcy mówili o ugodzie, lecz myśleli o likwidacji federacji ${ }^{63}$.

Ostatnim dniem ciszy przed burzą był 26 czerwca $1991 \mathrm{r}$. Pierwsza konfrontacja w wojnie w Słowenii zakończyła się bez rozlewu krwi na przejściu granicznym w Lazaret, w poblizu portu w Koper nad Morzem Adriatyckim. 26 czerwca we wczesnych godzinach porannych słoweńscy pracownicy, których zadaniem było zainstalowanie nowych drogowskazów do przejścia granicznego, zostali zatrzymani przez żołnierzy JNA oraz zmuszeni do przerwania pracy. Do podobnych incydentów doszło jeszcze w kilkunastu innych punktach na terytorium Słowenii. Zakończyły się one groźbami otwarcia ognia, nie doszło jednak do otwartego konfliktu militarnego.

Przed południem z Prezydium federacji przesłano faksem na ręce M. Kučana dwuczęściowe ultimatum, które, według zachodnich historyków, miało stanowić rodzaj wypowiedzenia wojny. Jednocześnie z garnizonów słoweńskich wyruszyły kolumny czołgów i wozów opancerzonych, lecz po przejechaniu kilkuset metrów natknęły się one na barykady ${ }^{64}$, polecono im więc, aby zawróciły do koszar.

\footnotetext{
62 J. Jansa, dz. cyt., s. 146-147.

${ }^{63}$ M.J. Zacharias, Komunizm..., s. 533.

64 The Battle for Slovenia, Ljubljana 1991, s. 9.
} 
Kolejnym krokiem władz federalnych było zamknięcie lotnisk międzynarodowych w Brnik w pobliżu Ljubljany oraz Mariborze. Nad Słowenią pojawiły się samoloty sił powietrznych, które rozpoczęły patrolowanie przestrzeni nad tą republika, doprowadzając do wstrzymania ruchu lotniczego $0^{65}$. 25 czerwca władze federalne przerzuciły transportem lotniczym z Serbii do bazy lotniczej w Cerklje kilkuset celników i milicjantów federalnych, którzy następnie mieli zostać przetransportowani na punkty graniczne, opanowane przez oddziały JNA, aby wznowić na nich służbę $e^{66}$.

Do pierwszych walk doszło następnego dnia, czyli 27 czerwca, kiedy kolumny pododdziałów armii federalnej rozpoczęły realizację pierwszego etapu planu, mającego doprowadzić do opanowania sytuacji w Słowenii. Zasadniczym celem grup bojowych JNA było zawładnięcie przejściami granicznych z Austria oraz Włochami i przywrócenie kierownictwa nad nimi władzom federalnym. Działania wojsk federalnych zostały poprzedzone wystapieniem dowódcy 5. OW, gen. K. Kolšeka, skierowanym do słoweńskiego premiera L. Peterle, w którym zapowiedziano przejęcie przez JNA kontroli nad ochroną granic oraz obronę suwerenności i całości terytorium federacji. W tym samym czasie samoloty JNA rozrzucały nad Słowenią ulotki zawierające groźby użycia przemocy oraz informujące, że władze federalne nie dążyły do starcia, lecz pragnęły rozmów i pokojowego rozwiązania konfliktu ${ }^{67}$.

27 czerwca trzy kolumny pancerne wyruszyły z trzech baz. Pierwsza kolumna, batalionowa grupa bojowa, złożona z lekkiego dywizjonu artylerii przeciwlotniczej z 306. lekkiego pułku artylerii przeciwlotniczej ${ }^{68}$ (306. lpaplot.) z Karlovaca w Chorwacji, została skierowana w stronę Ljubljany z zadaniem zajęcia lotniska Brnik. Druga kolumna, złożona z 1. batalionu czołgów 1. Brygady Pancerne ${ }^{69}$, wyruszyła z Vrhnika, kierując się w stronę lotniska w Brnik ${ }^{70}$. Trzecia kolumna, w skład której weszła grupa bojowa z 32. Brygady Zmechanizowanej ${ }^{71}$, udała się na północ z koszar JNA w Varaždinie w Chorwacji, w kierunku przejść granicznych z Austrią ${ }^{72}$. Wszystkie trzy kolumny zostały jednak zatrzymane przy pierwszych, prowizorycznych barykadach ustawionych przez grupy żołnierzy TO Słowenii. Zostały one też obsadzone przez oddziały uzbrojone $\mathrm{w}$ granatniki przeciwpancerne ${ }^{73}$.
65 Tamże.
${ }^{66}$ N. Baumkirher, dz. cyt., s. 56.
${ }^{67}$ The Battle for..., s. 17-18.
${ }^{68}$ D. Marijan, Slom Titove..., s. 198-199; Balkan Battlegrounds..., s. 60; Rat u Sloveniji, http://www.oklop.net23.net/jna/u_ratu.htm (dostęp 21 XI 2011).
${ }^{69}$ Balkan Battlegrounds..., s. 60.
70 E. Micheletti, Guerre en Slovénie: Indépendance de la Slovénie, „Raids” 1991, N. 63, s. 4.

${ }^{71} \mathrm{~W}$ sile wzmocnionego batalionu piechoty zmechanizowanej.

${ }^{72}$ M. Špegelj, Sjećanja vojnika, Zagreb 2001, s. 230-231.

73 J. Jansa, dz. cyt., s. 152-153; The Battle for..., s. 14-15. 
Do pierwszego starcia zbrojnego $\mathrm{w}$ trakcie wojny związanej z rozpadem Jugosławii doszło w rejonie miasta Metlika, gdzie oddziały słoweńskiego TO zaatakowały samobieżną baterię 306. lpaplot. Kolumnę ostrzelały i zatrzymały jednostki 2. (Doljenska) Dowództwa Regionalnego Obrony Terytorialnej Słowenii, starając się zablokować marsz sił federalnych. Po krótkiej wymianie ognia oraz negocjacjach kolumna ruszyła dalej. Słoweńcy ustawili jednak drugą blokadę (która dodatkowo została zaminowana) w pobliżu Medvedjek, gdzie bateria została ponownie zaatakowana i zatrzymana ${ }^{74}$.

Trzecia kolumna z 32. Brygady Zmechanizowanej, zablokowana została na moście, w pobliżu miasta Ormož, na granicy Słowenii i Chorwacji. Kolumna pancerna nie była w stanie pokonać przeszkód przygotowanych przez Słoweńców, nawet po tym, jak czołgi próbowały „rozstrzelać” blokujące drogę pojazdy ${ }^{75}$.

Począwszy od pierwszego dnia konfliktu JNA panowała niepodzielnie w powietrzu, wykonując kilka lotów patrolowych, nie atakowano jednak celów naziemnych. Janša oraz pozostali dowódcy sił słoweńskich zdawali sobie sprawę, że przewaga lotnictwa federalnego była miażdżąca. Dlatego też J. Janša wieczorem 27 czerwca wydał rozkaz, aby sekcje przeciwlotnicze rozpoczęły swoiste „polowanie” na samoloty bojowe i śmigłowce lotnictwa federalnego. Sądził on, że zestrzelenie samolotu lub śmigłowca JNA zmusiłoby pilotów do ograniczenia działań, a ponadto stanowiłoby dla dowództwa armii federalnej kolejną informację, że Słoweńcy posiadali zestawy przeciwlotnicze (w tym i rakietowe), byli więc przygotowani do prowadzenia walki z lotnictwem. Janša słusznie uważał, iż zestrzelenie samolotu mogłoby podnieść morale sił słoweńskich oraz osłabić chęć walki wojsk federalnych. Rzeczywiście, Słoweńcom udało się zestrzelić jeden śmigłowiec typu „Gazelle” ${ }^{76}$ oraz prawdopodobnie uszkodzić kilka innych. Fakt zniszczenia maszyny federalnej został odpowiednio nagłośniony w mediach (podano znacznie zawyżone straty). W istocie były one niewielkie i praktycznie nic nie znaczące, jednak ich wydźwięk był olbrzymi, zgodny z przewidywaniami Janšy ${ }^{77}$. Okazało się bowiem, że armia federalna nie ma do czynienia ze „zbieraniną faszystowskich nacjonalistów”, lecz z dobrze wyszkolonymi i wyposażonymi jednostkami wojskowymi.

W ciagu następnych kilkunastu godzin do walki wprowadzono kolejne jednostki: 13. Proletariacką Brygadę Zmotoryzowaną i 228. Brygadę Zmotoryzowana, które miały zająć przejścia graniczne w Fernetiči, Krvavi Potok, Vrtojba i Rožna Dolina, w pobliżu Nove Gorice. Część sił 13. Proletariackiej Brygady Zmotoryzowanej początkowo została zatrzymana na barykadach w rejonie Divače i Lokova,

\footnotetext{
${ }^{74}$ Balkan Battlegrounds..., s. 61.

75 M. Špegelj, dz. cyt., s. 231.

${ }^{76}$ E. Micheletti, $d z$. cyt., s. 4-6.

77 Balkan Battlegrounds..., s. 61.
} 
lecz po ich sforsowaniu oddziały dotarły do przejścia we Fernetiči. Druga kolumna brygady zajęła przejście w Krvavim Potoku ${ }^{78} .27$ czerwca kolumna 228. BZmot. po potyczce pod Škofiją i Novą Goricą pod koniec dnia doszła do Vipave. Jednak dopiero następnego dnia udało jej się osiagnaćc przejścia graniczne w Vrtojba i Rožna Dolina, w pobliżu Nove Gorice. Podczas marszu na przejście w Rožna Dolina jednostki federalne zostały zaatakowane przez TO, w trakcie walki zginęło kilku żołnierzy, a ponadto JNA straciła pięć czołgów T-55. 28 czerwca słoweńskie TO zaatakowały także przejście w Vrtojba. Pododdział 228. BZmot. po krótkiej walce poddał się, a Słoweńcy zdobyli siedem czołgów T-55, z których sformowano 6. kompanię czołgów w ramach 6. Sztabu TO (Pokrajinski štab za teritorialno obrambo, PŠTO).

Generalnie, do wieczora 27 czerwca jednostkom JNA udało się zrealizować pierwszy etap operacji, którym było opanowanie i zabezpieczenie przejść granicznych, tak aby można było wprowadzić tam urzędników federalnych. Słoweńcy zachowali kontrolę nad trzema przejściami z Austrią. Tymczasem pododdziały federalne uwikłały się $\mathrm{w}$ walki z wciąż atakującymi oddziałami słoweńskiej TO. Przedłużenie operacji niekorzystnie wpłynęło też na składy osobowe jednostek JNA. Dowódcy korpusów z nieznanych powodów nie wzmocnili jednostek czołgów należytymi siłami piechoty i artylerii ${ }^{79}$. W toku walk doszło do 72 potyczek o różnej intensywności. Słoweńcom udało się zablokować większość oddziałów pancernych i zmechanizowanych w koszarach JNA (m.in. 165 czołgów i 68 samobieżnych zestawów artyleryjskich $)^{80}$. Straty JNA w tym dniu wyniosły: 4 oficerów i 16 rannych żołnierzy.

Późnym rankiem, w piątek, 28 czerwca nasiliły się walki w całej Słowenii, przybierając charakter starć na pełną skalę. Kiedy JNA starała się wykorzystać swoją przewagę techniczna, Słoweńcy skupili główny wysiłek na odebraniu JNA inicjatywy i związaniu walką wszystkich jednostek bioracych udział w interwencji. Ponadto rozpoczęli ścisłą blokadę wszystkich kompleksów koszarowych, baz i składnic federalnych. Odcięto dostawy prądu i wody oraz połączeń telefonicznych. W ten sposób w ciagu kilkunastu godzin od rozpoczęcia walk Słoweńcy odseparowali od Dowództwa 5. OW wszystkie garnizony 14. i 31. korpusów.

28 czerwca od rana starcia trwały także na przejściach granicznych. Słoweńskim jednostkom TO udało się odzyskać panowanie nad kilkoma z nich, które 27 czerwca przed północą zostały zdobyte przez $\mathrm{JNA}^{81}$. Szczególnie ciężkie walki rozgorzały w rejonie przejścia granicznego Gornja Radgona. Dlatego też dowództwo federalne zdecydowało się na użycie kolejnych jednostek 10. (Zagrzeb) i 13. (Rijeka) korpusów oraz lotnictwa taktycznego, które miało wesprzeć oddziały
${ }^{78}$ Rat u...
79 О. Валецкий, dz. cyt., s. 15.
80 J.J. Švajncer, Vojna in vojaška zgodovina Slovencev, Ljubljana 1992, s. 214.
${ }^{81}$ Balkan Battlegrounds..., s. 62. 
JNA, walczące z jednostkami milicji i TO. 28 czerwca, oprócz nalotów w rejony bezpośrednich walk, siły powietrzne federacji wykonały szereg uderzeń w strategiczne obiekty Słowenii. Samoloty RV zbombardowały lotniska w Ljubljanie ${ }^{82}$ oraz Mariborze. Zaatakowano także dowództwo słoweńskiej TO w Kočevskiej Reca.

Tego samego dnia wprowadzono do walki grupę bojową 140. Brygady Zmechanizowanej, która jednak po przekroczeniu granicy słoweńsko-chorwackiej została zablokowana w rejonie Trebnje na północny zachód od miasta Novo Mesto.

Mariborska 195. BZmot. otrzymała zadania zajęcia przejść w Šentilju i Dravogradzie. Kolumna tej brygady, zanim je osiągnęła, musiała stoczyć ciężkie walki pod Strihovcem. Wspierana przez lotnictwo, dopiero 28 czerwca zdobyła Šentili ${ }^{83}$. Następnego dnia kolumna zmotoryzowana (złożona z pododdziałów 31. bVP oraz 31. krozpozn.), wsparta dwoma czołgami T-55 195. BZmot., która miała pomóc walczącym oddziałom brygady na przejściu granicznym, została zatrzymana przez pododdziały 7. (Vzhodnostajerska) Oddziału TO. Słoweńcom udało się zniszczyć najpierw czołgi, a następnie rozproszyć piechotę. Druga kolumna brygady mariborskiej została zaatakowana koło Dravogradu. Tylko pięć jej wozów dotarło do przejścia. Łącznie w walce w tym rejonie JNA straciła dwanaście czołgów i jeden SO M-36, które zostały zdobyte przez siły 7. PŠTO. 2 lipca siły TO uderzyły na Dravograd i Šentilj, ostatecznie likwidując znajdujące się tam pododdziały JNA.

28 czerwca słoweńskie pododdziały sił specjalnych, m.in. 1. BMORiS zaatakowały kolumnę czołgów i transporterów opancerzonych z 253. BZmot. w Novej Goricy i zniszczyły trzy czołgi T-55, a kolejne trzy zdobyły ${ }^{84}$. Słoweńcom udało się także opanować magazyny w mieście Borovica, w których była zgromadzona amunicja i materiały saperskie (także miny przeciwpiechotne i przeciwpancerne) oraz składy wyposażenia i umundurowania w Leskovcu i Drulovce. 29 czerwca położenie wojsk federalnych stało się wręcz katastrofalne, dlatego też dowództwo JNA ogłosiło jednostronne przerwanie ognia. Ljubljana początkowo zignorowała tę propozycję. Wieczorem jednak prezydent Słowenii M. Kučan oraz admirał Stane Brovet, zastępca sekretarza obrony narodowej, nawiązali kontakt telefoniczny $\mathrm{z}$ Belgradem, wyrażając $\mathrm{w}$ końcu zgodę, by zawieszenie broni rozpoczęło się o godz. 21.00 czasu lokalnego. W następnym dniu natomiast miano kontynuować rozmowy w celu ustalenia dokładnych warunków ${ }^{85}$.

Pomimo trwających rozmów w sprawie rozejmu i ewentualnego zakończeniu kryzysu, 29 czerwca Słoweńcom udało się zajać kolejne przejścia graniczne i zdobyć bazy materiałowe JNA. Nie wszystkie jednak działania mające prowadzić do przejęcia magazynów zakończyły się powodzeniem. Sierżant Dragomir

\footnotetext{
${ }^{82} \mathrm{~W}$ trakcie nalotu zginęło dwóch dziennikarzy austriackich.

${ }^{83} \mathrm{Z}$ czołgów zdobytych przez 7. PŠTO utworzono 7. kompanię czołgów.

${ }^{84}$ Balkan Battlegrounds..., s. 62.

${ }^{85}$ The Battle for..., s. 41.
} 
Grujnović, który przejął dowodzenie ${ }^{86}$ w składnicy paliw JNA w Mokronovo, zagroził wysadzeniem magazynów. $\mathrm{W}$ ten sposób doprowadził nie tylko do wycofania się oblegających składnicę sił słoweńskich, ale także do odblokowania kolumny JNA pod miastem Krško ${ }^{87}$. Był to jednak tylko jeden z nielicznych aktów heroicznej obrony ze strony żołnierzy $\mathrm{JNA}^{88}$.

Innym problemem występującym prawie od początku konfliktu były dezercje, które nasilały się w miarę upływu czasu ${ }^{89}$. Ponadto wielu rezerwistów nie stawiło się w jednostkach, w których ogłoszono mobilizację, np. sarajewskiego i belgradzkiego garnizonu ${ }^{90}$. Nawet oddziały 1. Gwardyjskiej Proletariackiej Dywizji Zmechanizowanej, które otrzymały rozkaz wymarszu, nie dość, że wyruszyły z opóźnieniem, to nigdy do Słowenii nie dotarły. Wśród dezerterów przeważali żołnierze pochodzenia słoweńskiego, chorwackiego, lecz zdarzali się również i albańskiego oraz serbskiego ${ }^{91}$. Wśród kadry zawodowej JNA decyzja o interwencji w Słowenii także nie cieszyła się poparciem. Wystarczy przytoczyć dane dotyczące zwolnień lekarskich, jakie otrzymali oficerowie i podoficerowie garnizonu zagrzebskiego ${ }^{92}$.

Należy podkreślić, że pierwsza faza wojny zakończyła się częściowym sukcesem taktycznym JNA, ale jednocześnie zarysował się jej poważny kryzys na poziomie operacyjnym. Wydawało się, że JNA nie miała żadnego planu, jak kontynuować działania. Walczące pododdziały oraz dowództwo korpusów, były częściowo zdezorientowane i nikt tak naprawdę nie wiedział, co należało zrobić po opanowaniu przejść granicznych. Słoweńcy spodziewali się, że ich walkę poprą Chorwaci, z którymi zawarli ustne porozumienie o wspólnej obronie, lecz polityczni przywódcy, na czele z F. Tuđmanem, nie podjęli żadnych działań ${ }^{93}$.

${ }^{86}$ Sierżant D. Grujnović był najstarszym stopniem żołnierzem w bazie, ponieważ pozostali oficerowie i podoficerowie (w większości Słoweńcy) zdezerterowali. D. Marijan, Slom Titove..., s. 206.

87 О. Валецкий, $d z$. cyt., s. 19.

88 Nie wiadomo, dlaczego przykłady waleczności żołnierzy JNA były pomniejszane i przemilczane.

${ }^{89}$ M. Špegelj, dz. cyt., s. 231.

${ }^{90} \mathrm{Na}$ przykład rezerwiści powołani do 169. Brygady Zmechanizowanej odmówili marszu do Słowenii. О. Валецкий, dz. cyt., s. 15.

91125 Słoweńców, 101 Chorwatów, 47 Albańczyków i 20 Serbów. D. Marijan, Slom Titove..., s. 210; Balkan Battlegrounds..., s. 63.

92 Do połowy lipca $1991 \mathrm{r}$. do gabinetów psychiatrycznych zgłosiło się 627 żołnierzy, 146 oficerów i podoficerów zawodowych. Z tego na leczenie zatrzymano ponad 48\% zgłoszonych, a 35\% skierowano na komisję lekarską w celu orzeczenia o przydatności do służby wojskowej. Jeśli chodzi o kadrę zawodowa, sytuacja przedstawiała się jeszcze gorzej, aż $47 \%$ otrzymało bowiem zwolnienie lekarskie, natomiast leczenie zastosowano wobec $30 \%$. D. Marijan, Slom Titove..., s. 211.

${ }_{93}$ M. Špegelj, dz. cyt., s. 227-228. 
ROZEJM (29 CZERWCA - 2 LIPCA)

W trakcie rozmów na temat zawieszenia broni gen. V. Kadijević bezskutecznie wywierał nacisk, by przeprowadzić zdecydowany atak, który miałby trzy cele: ujarzmienie Słowenii, zachowanie integralności terytorialnej Jugosławii oraz przywrócenie prestiżu JNA. 30 czerwca na spotkaniu Prezydium Związkowego Kadijević wyraził opinię, że pierwszy plan JNA - ograniczona operacja zmierzająca do zabezpieczenia przejść granicznych z Włochami i Austria - nie powiódł się. Za niepowodzenie obwiniono dotychczasowego dowódcę 5. OW, gen. K. Kolšeka, który został zdymisjonowany, a zastapił go gen. Života Avramovic $^{94}$. Plan opracowany w federalnym Sztabie Generalnym zakładał przeprowadzenie skoncentrowanych uderzeń wzmocnionymi grupami bojowymi w rejonie Ljubljany i Mariboru, zajęcie stolicy i Mariboru, opanowanie kluczowych obiektów, aresztowanie władz i zakończenie buntu. Operacja miała być poprzedzona lotniczymi uderzeniami taktycznymi na strategiczne obiekty republiki. Jej czas ustalono na 8-10 dni. W działaniach miały wziąć udział wszystkie korpusy 5 . $\mathrm{OW}^{95}$. Ku zaskoczeniu Kadijevicia, gabinet federalny podją odmienną decy$z_{j e}{ }^{96}$, postanowił bowiem dalej prowadzić rozmowy ${ }^{97}$.

\section{WZNOWIENIE WOJNY (2-4 LIPCA)}

Po trzydniowym okresie ciszy, trwającym od 29 czerwca do 1 lipca, działania wojenne zostały 2 lipca wznowione. Tego ranka gen. B. Adžić nakazał rozpoczęcie drugiej fazy operacji wojsk federalnych. Zreszta, pomimo obowiązywania rozejmu, nadal dochodziło do walk. Słoweńcy zacieśnili blokady i przeprowadzili uderzenia, w wyniku których kilka kolejnych garnizonów JNA poddało się siłom Obrony Terytorialnej Słowenii ${ }^{98}$. Zanim jeszcze 2 lipca wznowiono walki, Słoweńcy odzyskali kontrolę nad ponad połową przejść granicznych ${ }^{99}$.

${ }_{94}$ D. Marijan, Slom Titove..., s. 206.

95 Tamize, s. 204.

${ }^{96}$ L. Silber, A. Little, dz. cyt., s. 106-108.

${ }_{97}$ Eric Micheletti w jednym ze swoich artykułów na łamach czasopisma „Raids” sugerował, że w Belgradzie doszło do zamachu wojskowego, podczas którego wojsko przejęło władzę. Dlatego 2 lipca rozpoczęto, wbrew decyzjom federalnym, działania militarne, co w świetle ustaleń innych autorów, m.in. Davora Marijana, jest nieprawdą. Należy też zwrócić uwagę na tendencyjny charakter artykułów tego i wielu innych zachodnich dziennikarzy oraz (niestety) historyków. E. Micheletti, dz. cyt., s. 6-9.

98 Między innymi dwa bataliony 345. Brygady Alpejskiej.

${ }^{99}$ Do 30 czerwca praktycznie wszystkie przejścia graniczne z Austrią znalazły się z powrotem w rękach secesjonistów. The Battle for..., s. 41, 58. 
Dzień 2 lipca okazał się decydujący dla przebiegu całego starcia, Słoweńcom udało się bowiem przejąć całkowicie inicjatywę, a przede wszystkim zdobyć pozostałe przejścia graniczne ${ }^{100}$. Ponadto opanowali garnizon 345 . Brygady Alpejskiej w Škofja Loka, który przeszedł na ich stronę $e^{101}$.

2 lipca lotnictwo federalne wznowiło naloty ${ }^{102}$, atakując przekaźniki radiowe i telewizyjne. Zbombardowano także lotnisko w Ljubljanie (właściwie w mieście Brnik) ${ }^{103}$. Samoloty RV kontynuowały też uderzenia taktyczne na koszary TO w Kočevskiej Rece oraz na barykady w rejonie Catezu, Krakovskiego Gozdu i Dravogradu.

Po uderzeniach lotniczych do Słowenii wyruszyły kolejne jednostki z garnizonów w Chorwacji. Z Zagrzebia maszerowała wzmocniona grupa brygadowa ze 140. Brygady Zmechanizowanej, która w godzinach wieczornych i porannych 3 lipca toczyła zacięte walki w rejonie Gornja Vas, gdzie ostatecznie została zatrzymana.

2 lipca z garnizonu Jastrebarsko wyruszyła batalionowa grupa bojowa z 4. Brygady Pancernej (kilkadziesiąt czołgów M-84, T-55, bwp M-80 i transporterów M-60), która miała uwolnić zamknięty w rejonie Krakovskiego Gvozdu lekki dywizjon artylerii przeciwlotniczej z 306. lpaplot. oraz pododdział zmechanizowany tej brygady, walczący od 27 czerwca z oddziałami TO w rejonie Bregani i Dobova. Po przekroczeniu granicy kolumna pancerno-zmechanizowana stoczyła w rejonie miasta Brezice pierwszą potyczkę, niszcząc barykadę słoweńskich sił TO. W rejonie Prilipa kolumna została jednak ponownie zaatakowana przez oddziały słoweńskie ${ }^{104}$. Grupa wdała się w walkę, podczas której jej dowódca popełnił wiele błędów, wpływających niekorzystnie na sytuację jednostki JNA. Kolumna została zatrzymana. W związku z zaistniałą sytuacją dowódca grupy wezwał na pomoc lotnictwo. Samoloty RV jednak zamiast zaatakować pozycje TO, uderzyły omyłkowo na kolumnę JNA ${ }^{105}$. Poległo kolejnych 3 żołnierzy, a 19 zostało rannych, m.in. dowódca grupy bojowej. Oznaczało to koniec misji żołnierzy brygady jastrebarskiej.

W tym samym czasie oddziały z 25 . Obm ŠTO (Območni štab teritorialne obrambe) 2. (Doljenska) PŠTO zaatakowały kolumnę lekkiego dywizjonu artylerii przeciwlotniczej z 306. lpaplot. Uderzenie to przyniosło kolejne straty w sprzęcie i ludziach w jednostce JNA. Na wyczerpaniu było paliwo i amunicja.

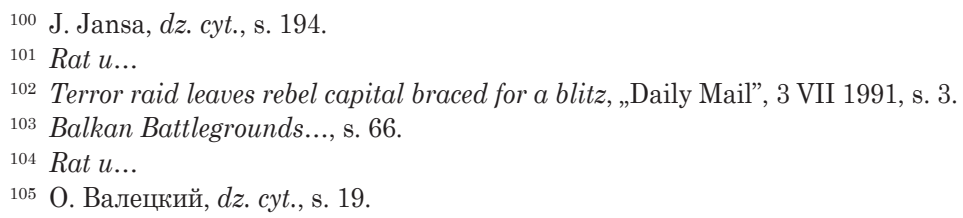


Sytuacja dywizjonu stała się beznadziejna ${ }^{106}$. Gdy dowódca kolumny otrzymał informację, że grupa bojowa 4. Brygady Pancernej została zatrzymana i poniosła znaczne straty, zostawił pojazdy i próbował przedrzeć się przez otaczające go pododdziały słoweńskiego TO. Wyjście z kotła jednak się nie powiodło, a Słoweńcy wzięli do niewoli około 100 żołnierzy armii federalnej ${ }^{107}$.

2 lipca w godzinach południowych oddziały TO, przy wsparciu grupy sił specjalnych oraz czołgów z 7. kompanii czołgów, rozbiły zgrupowanie 195. Brygady Pancernej pod Šentiljem i opanowały przejście graniczne, o które od kilku dni toczono ciężkie boje. Na przejściu pod Ferentiči do końca dnia prowadzone były zacięte walki z broniącymi się oddziałami JNA, które w końcu musiały się poddać. Pododdziały słoweńskiego TO z 61 . Obm ŠTO zdobyły po krótkim, lecz gwałtownym starciu, skład amunicji JNA koło Novej Goricy.

Informacje napływające do Sztabu Generalnego federacji były niepomyślne. Jednostki JNA wycofywały się lub poddawały oddziałom TO. Słoweńcom udało się odzyskać wszystkie przejścia graniczne i ponownie ustanowić kontrolę nad granicami republiki. W tej sytuacji związkowy sekretarz obrony gen. B. Adžić zwrócił się do władz republikańskich z prośbą o zawieszenie broni. Pod koniec 2 lipca walki zaczęły powoli wygasać, zwłaszcza że prezydent Słowenii w odpowiedzi na prośbę dowództwa federalnego wieczorem ogłosił zawieszenie broni ${ }^{108}$. Rozpoczęto wstępne rozmowy. Dowództwo TO na czele z J. Janšą żądało, aby wojska federalne opuściły terytorium Słowenii, pozostawiając broń i sprzęt ${ }^{109}$. Nie wyrażały jednak na to zgody ani federalny Sekretariat Obrony Narodowej, ani Sztab Generalny. Doszło więc do impasu w rozmowach. Prezes Rady Ministrów Słowenii L. Peterle postanowił mimo wszystko ogłosić jednostronna, czteropunktową propozycję zawieszenia broni, która zakładała, że jednostki JNA mogły powrócić do koszar ze sprzętem i uzbrojeniem. Ostatecznie wstępne zawieszenie broni weszło w życie wieczorem 3 lipca.

Oficjalne rozmowy pokojowe rozpoczęły się na poczattku lipca na Wyspach Briońskich, położonych na Morzu Adriatyckim ${ }^{110}$. W ich trakcie przedstawiciele rządu federalnego Jugosławii, Słoweńcy oraz Chorwaci spotkali się pod auspicjami zespołu reprezentującego ministrów spraw zagranicznych Wspólnoty Europejskiej i ostatecznie, po intensywnych negocjacjach, podpisane zostało tzw. porozumienie briońskie. Na jego mocy wszystkie rządy republikańskie Jugosławii zgodziły się rozpoczaćc przed 1 sierpnia $1991 \mathrm{r}$. negocjacje na temat przyszłości kraju, zaakceptować obserwatorów Wspólnoty Europejskiej, znieść

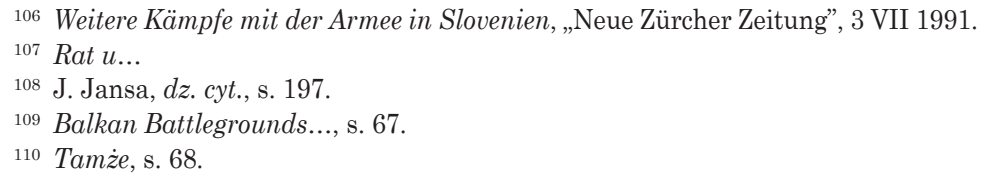


blokady koszar oraz skierować siły TO i policji do miejsc dotychczasowego stacjonowania. Władze Słowenii podjęły się zdemobilizowania części sił TO. Armia federalna miała pomóc usuwać szkody, będące pokłosiem konfliktu, dotyczyło to m.in. usuwania pól minowych oraz zniszczonych pojazdów.

W wyniku działań wojennych w Słowenii zginęło 44 żołnierzy JNA, a 187 zostało rannych. Straty słoweńskie wyniosły natomiast 8 poległych żołnierzy i policjantów oraz 19 osób cywilnych.

\section{Podsumowanie}

Można przyjąć, że pod wieloma względami wojna tocząca się w Słowenii w ogóle nie dotyczyła tego kraju. Od początku prawdziwą jej istotą była nie tylko kwestia niepodległości jednej z republik wchodzących w skład Jugosławii, lecz w ogóle przyszłość federacji jugosłowiańskiej. Zachodni politolodzy, historycy, dziennikarze podkreślaja, że Belgradowi opanowanemu przez Serbów chodziło zaś tylko o powstanie „Wielkiej Serbii”. Czy takie stanowisko jest uzasadnione? Kwestie te są bardziej skomplikowane niż argumenty przytaczane w literaturze przedmiotu. Dążenia secesjonistyczne Słowenii były z pewnością nie do przyjęcia zarówno dla władz federalnych, jak i zdobywających coraz większe znaczenie polityków serbskich, na czele ze S. Miloševiciem. Prowadziły bowiem do niebezpiecznego precedensu, co było sprzeczne z interesem władz federalnych. Lokalni przywódcy zarówno dotychczas rządzącej partii komunistycznej, jak i powstałych licznie nowych ugrupowań politycznych byli natomiast goracymi zwolennikami rozwiązania siłowego, ponieważ zależało im na zdobyciu władzy. Należy podkreślić, iż przywódcy słoweńscy od początku dążyli do wojny, zaplanowali walkę i chcieli ją rozegrać w dogodnym dla siebie czasie.

Dlaczego jednak JNA poniosła klęskę? Na to pytanie można jednoznacznie odpowiedzieć: bo nie była przygotowana do wojny wewnętrznej. Dowództwo także nie stanęło na wysokości zadania, nie wypracowało bowiem planów działania, ani też nie miało odpowiednich sił, by zrealizować operację w Słowenii. Wśród żołnierzy nie było woli walki. Znawcy problematyki na Zachodzie, podkreślający niewłaściwe wyszkolenie, jak również przestarzałą teorię walki, mają tylko częściowo rację. Wojna ta bowiem została przegrana, zanim się jeszcze, tak naprawdę, rozpoczęła. Wygrali ją przede wszystkim Słoweńcy, którzy zniwelowali przewagę techniczna sił federalnych. Wykorzystali teren, doskonale podzielili siły (ekonomia sił), perfekcyjnie zastosowali zwrotne, lekkie, uzbrojone w broń przeciwpancerną pododdziały. Atakowali silnego przeciwnika, zadając mu znaczne straty na kolejnych rubieżach obrony. I ostateczny, jak się wydaje najważniejszy, czynnik, polegający 
na tym, że w wojnie wzięła udział cała ludność Słowenii. Armii federalnej przyszło więc walczyć z całym społeczeństwem. Takiej wojny nikt jeszcze nie wygrał, dlatego nie mogła tego dokonać także JNA. Ponadto Słowenia odniosła sukces na arenie międzynarodowej. Wojsko i rząd federalny, dzięki umiejętnie przeprowadzonej wojnie informacyjnej, były postrzegane zarówno przez społeczność międzynarodowa, jak i polityków zachodnioeuropejskich jako agresor. Powstałe wówczas opinie i ugruntowane stereotypy o zbrodniczych Serbach po kolejnych konfliktach, w Chorwacji i Bośni, urosły niemal do poziomu apokaliptycznego zła. 